\title{
Ground water as the main factor differentiating the natural vegetion in a landscape phytocomplex ("Grabowy" range in the Kampinos Forest Complex)
}

\author{
JAN MAREK MATUSZKIEWICZ
}

Institute of Geography and Spatial Organisation, Polish Academy of Sciences, Krakowskie Przedmieście 30, 00-927 Warszawa, Poland

(Received: July 30, 1980)

\begin{abstract}
In the period 1973-1975 the depth of the ground water level and the moisture of the surface soil layer were investigated in various plant communities of the "Grabowy" range in the Kampinos Forest Complex (central Poland). The studies included a fragment of a landscape phytocomplex within which eight types of forest plant communities were distinguished. It was found that the plant communities change parallelly to the differences in the soil-water conditions (ground water level, physical properties and moisture of soils) in space.
\end{abstract}

\section{INTRODUCTION}

Within the framework of phytosociological investigations carried on in the "Grabowy" range in the Kampinos Forest Complex (C z e r w in ski et al. 1974, K olczak 1974, Matuszkiewicz W. 1974) studies were undertaken of the seasonal dynamics of the ground water level and soil moisture in various plant communities.

The aim in view was to gain a knowledge of the seasonal variations of the ground water horizon and soil moisture in various plant communities and of the relations between the spatial differentiation of the vegetation and the variability of the water conditions in a landscape vegetation unit.

\section{OBJECT INVESTIGATED}

The studies were performed in the "Grabowy" range in the eastern part of the Kampinos Forest. This range of 3.7 ha consists of a sandy 
eminence and swampy depressions on both its sides. The southern depression is a part of the valley of a small water course, whereas in the northern ore water run-off is restricted. The "Grabowy" range is characterised by a high homogeneity of the primary geological substrate which consists of sands of a diluvial river terrace. In both depressions the sands are covered by a peat layer. The soil surface is differentiated into podsoils, gley soils, black turf soil and peat soils (C z e rwiński et al. 1974).

The vegetation of this range is also differentiated and highly complex (Fig. 1). The forest communities appearing here belong to four plant associations: Pino-Quercetum Kozł. 1925, Tilio-Carpinetum Tracz. 1962, Circaeo-Alnetum Oberd. 1933 and Carici elongatae-Alnetum Koch 1926 (K w olc zak 1974).

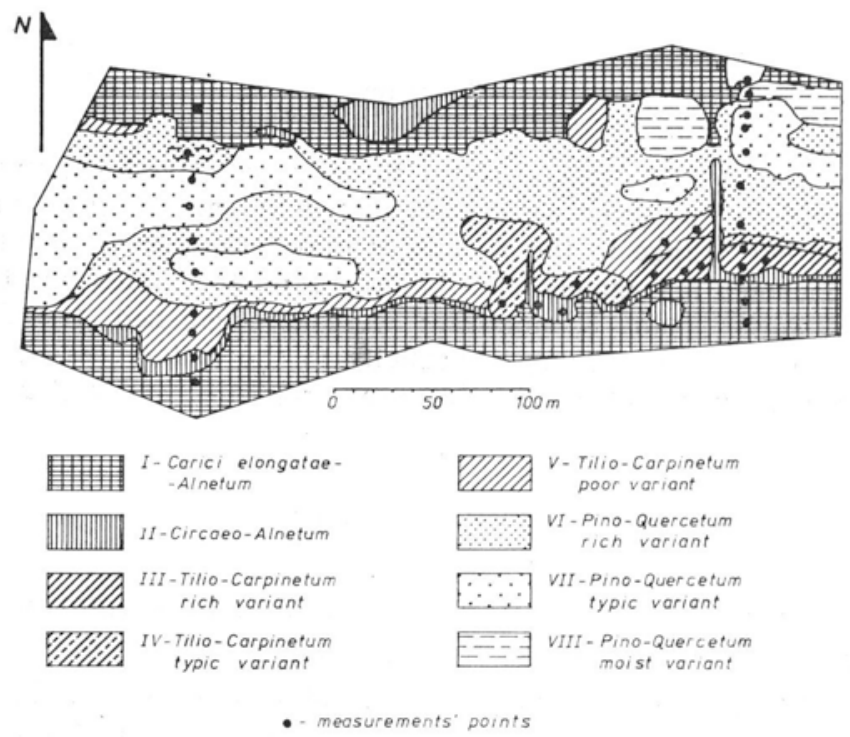

Fig. 1. Plant communities of the "Grabowy" range (after K w ol c zak 1974 modified)

The "Grabowy" range may be considered as a fragment of a landscape phytocomplex (M a t us zkie wi c z J. M. 1978, 1979a) the structure of which is shown according to the diagram adopted by the author (Fig. 2). This range is a suitable object for investigations on the structure of landscape phytocomplexes since we are dealing here with differentiation of only one of the primary habitat factors, that is the water conditions, whereas other factors (e.g. the kind of geological substrate, climate) are equal. 


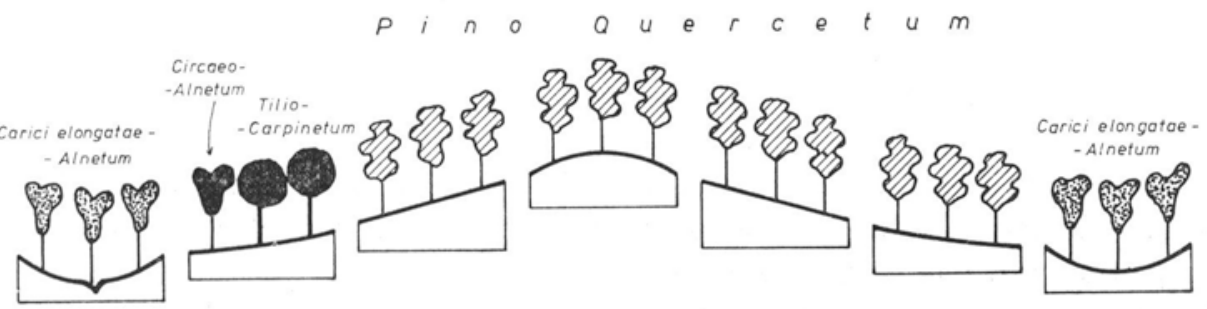

Fig. 2. Diagram of vegetation structure in the landscape phytocomplex

\section{METHODS}

For checking the ground water level 34 sites were chosen in the "Grabowy" range, 16 of which served also for establishing the soil moisture. These sites were localised in parts where the phytosociological characteristic of the plant communities was unequivocal ( $\mathrm{K} \mathrm{w} \mathrm{olc} \mathrm{zak}$ 1974). Eight types of plant communities were taken into account and denoted by Roman numerals: I - alder forest (Carici elongatae-Alnetum) - sites 1, 10, 21, 22; II - ash-alder floodplain forest (Circaeo-Alnetum) - sites 9, 20, 29, 31, 32; III — oak-hornbeam forest (Tilio-Carpinetum) the rich variant - sites 18, 19, 23, 25, 28; IV - (Tilio-Carpinetum typicum) - sites 30, 33, 34; V - (Tilio-Carpinetum) the poor variant — sites 7, 8, 24, 27; VI — mixed coniferous forest (Pino-Quercetum) the rich variant - sites 5, 16, 17; VII - mixed coniferous forest, the typical variant - sites_3, 4, 6, 13, 14, 15; VIII - mixed moist coniferous forest - sites 2,12 . Site 11 was situated for purposes of comparison in the periodical water body.

At all sites small wells were dug with wood casing and in the period 1973-1975 the ground water horizon was measured every two weeks with an accuracy of $\pm 1 \mathrm{~cm}$. Soil samples were taken in the immediate vicinity of part of the wells from the surface soil layer (usually horizon $A_{1}$ ) for moisture determination. The soil samples were taken with a sampling stick and placed immediately in tightly closed glass vessels, weighed and dried at $105^{\circ} \mathrm{C}$ for $36 \mathrm{~h}$ and then weighed once more. The water weight was calculated to $100 \mathrm{~g}$ of dried soil. The physical properties of the soils were determined once: specific gravity, volume weight, porosity, capillary water capacity, permeability to air and volume of solid particles. With these data available, the water content in the particular samples was calculated in millilitres per $100 \mathrm{~cm}^{3}$ soil with intact structure as well as the degree of saturation of the capillary capacity (in $\%$ ). Soil moisture was determined on sites $3,4,5,6,9,10,14,15$, $16,18,19,24,27,28,29,33$. 


\section{RESULTS AND DISCUSSION}

SEASONAL DYNAMICS OF GROUND WATER HORIZON

The results of measurement of the ground water horizon (Fig. 3) demonstrated marked seasonal variations of this factor. The annual amplitudes range from $62-94 \mathrm{~cm}$ and vary in the particular seasons, they are different in various plant communities. The highest ground water levels occur usually in winter. Beginning with March the ground water horizon falls and this continues at various rates up to July. In the second half of this month there occurred in two seasons $(1973,1975)$ a marked rise of the ground water lasting but a short time. In August, September and partly in October the ground water horizon fell distinctly, with at the end of October either a drastic rise of the water level (1973 and 1974) or a slow rise up to December (1975).

It is rather difficult to establish a regularity in the seasonal variations of the ground water horizon on the basis of the results obtained because of the rather untypical distribution of precipitation in the period of study (Fig. 3). However, 4-6 periods may be distinguished in the annual cycle as regards the ground water horizon, the widest differences between the successive years appearing in early summer and in autumn. This result confirms the observations to date (F a bijan owski and Zarzycki 1967, Ug g la and Uggla 1979).

\section{DEPENDENCE OF PRESENCE OF PLANT COMMUNITIES ON THE GROUND WATER HORIZON}

The depth of the ground water shows distinct differences in the "Grabowy" range. The spatial variability of the water horizon along two transects (Fig. 4) can be easily correlated with vegetation variability. Curves of the annual ground water horizon variations (Fig. 3) show differences in the habitats of the particular plant community types. This is also visible in Table 1, where the mean water levels in the period of study are listed. If we order the plant communities according to the depth of the ground water, a sustained sequence of communities appears. This sequence agrees with the numbering of the communities, the mixed coniferous forest community excepted (VIII) which occupies the position between the floodplain forest (II) and the Tilio-Carpineta (III, IV).

The frequency of appearance of definite levels of the ground water in the particular plant communities is interesting (Fig. 5). As seen, the most frequent horizons in the particular communities are higher than those calculated in Table 1 as mean states. The particular curves exhibit 
$A$

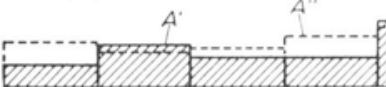

$\mathrm{cm}$
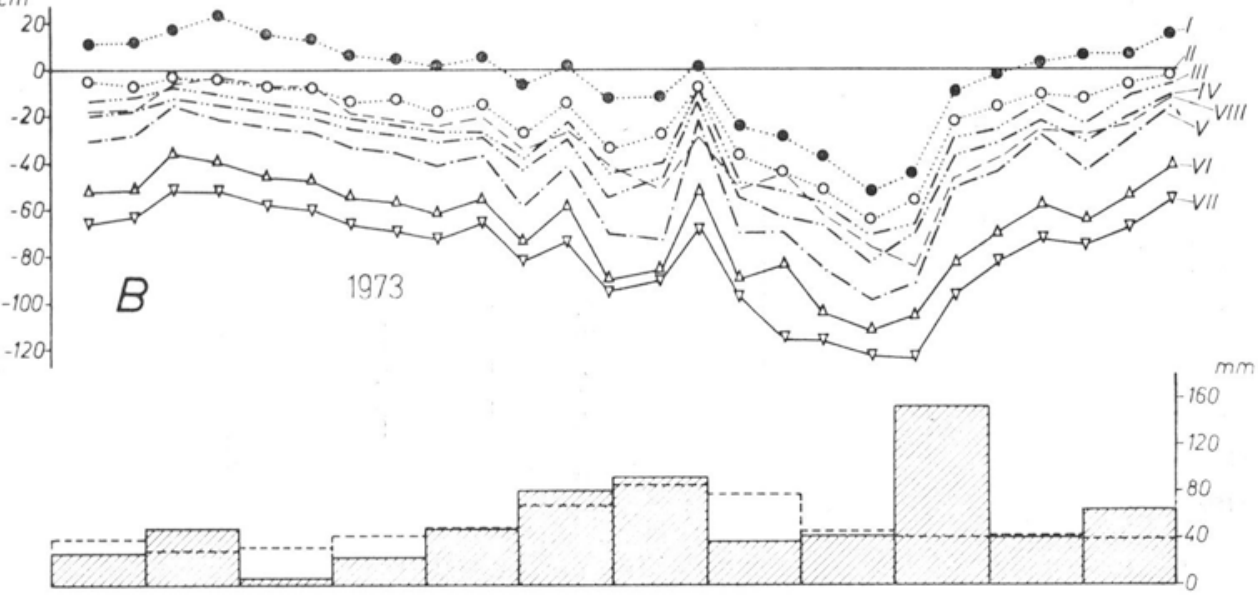

$\mathrm{cm}$
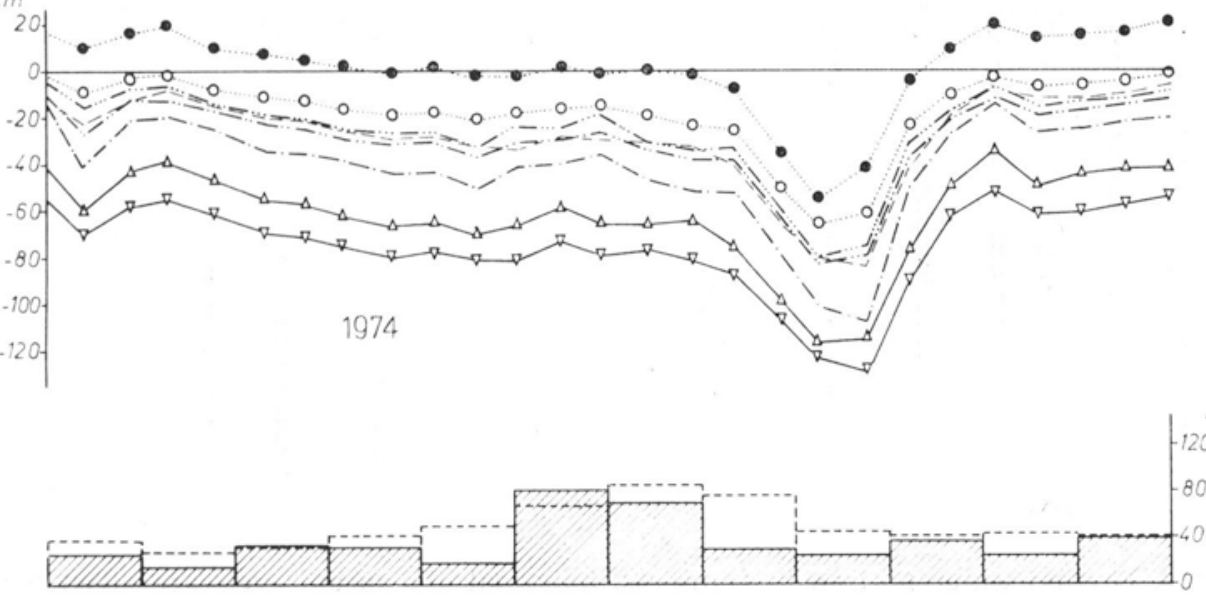

$\mathrm{cm}$

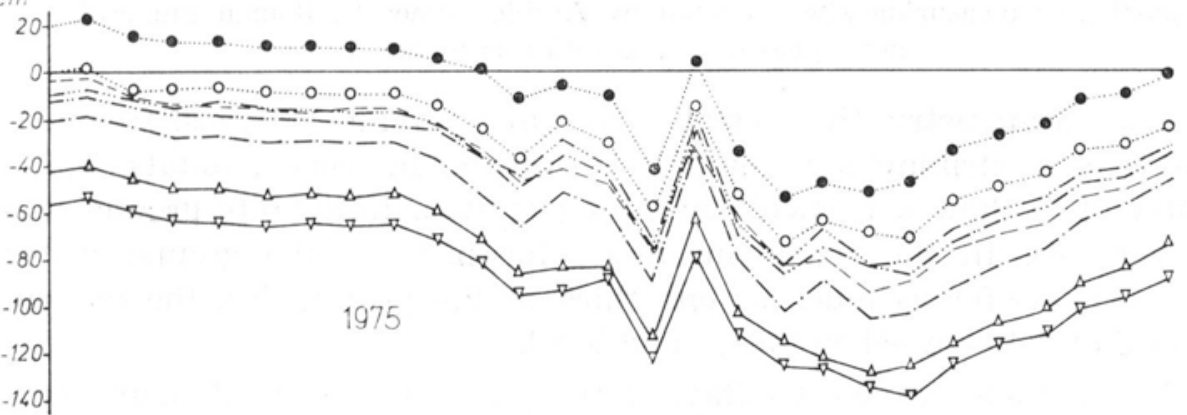

Fig. 3. Precipitation amount (A) and ground water horizon (B) in the period 1973-1975 in the "Grabowy" range. Plant communities (I-VIII) as in Fig. 1. A' monthly sum of precipitation in the studied period. A" - means of monthly precipitation for a many years' period (data from meteorological station Nowy Dwór Maz., about $10 \mathrm{~km}$ distant from investigated area) 

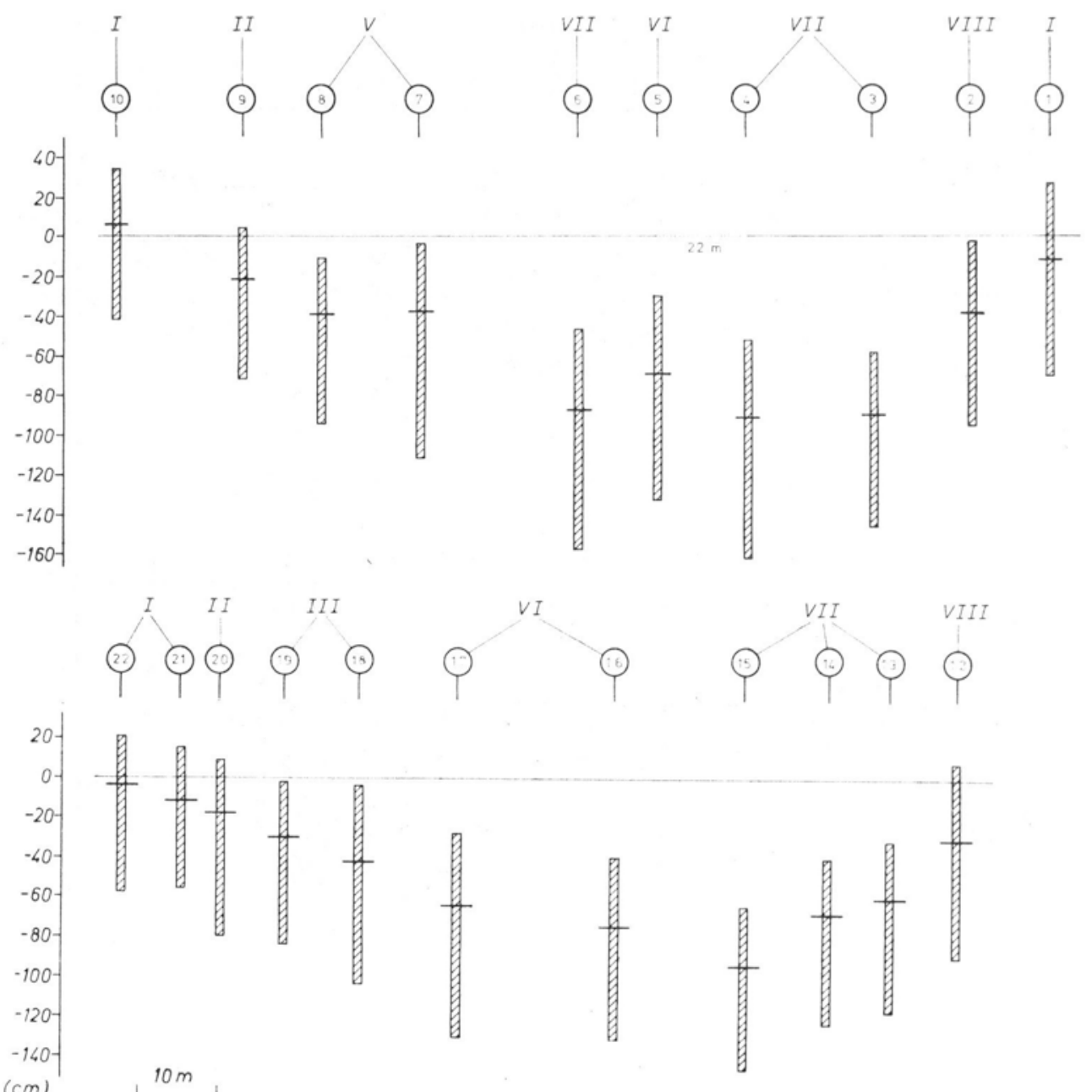

Fig. 4. Ground water horizon in transects. Extremal and mean levels are given for the particular measuring sites denoted by Arabic numerals. Roman numerals denote types of communities as in Fig. 1

a distinct asymmetry, that is states close to maximum are most frequent. This is most striking in communities growing in moist habitats. These communities show a particularly strong relation to definite ground water horizons. In the floodplain forest for instance the ground water level remains for as much as one third of the year within the narrow interval of $0-10 \mathrm{~cm}$ below the ground level.

The character of the habitats of the particular types of plant communities according to the ground water horizon is distinct. The Carici elongatae-Alnetum communities occupy habitats flooded for long periods. As seen, the annual innundation is a basic habitat factor conditioning the existence of these communities. The depth of the innun- 


\section{Table 1}

Depth of ground water horizon in plant communities of "Grabowy" range

\begin{tabular}{|l|r|r|c|c|}
\hline \multirow{2}{*}{ Plant communities } & \multicolumn{4}{|c|}{ Depth of water horizon, cm } \\
\cline { 2 - 5 } & $\mathrm{a}$ & $\mathrm{b}$ & $\mathrm{c}$ & $\mathrm{d}$ \\
\hline $\begin{array}{c}\text { Carici elongatae- } \\
\text {-Alnetum (I) }\end{array}$ & 22.3 & -54.1 & 76.4 & -4.5 \\
$\begin{array}{c}\text { Circaeo-Alnetum (II) } \\
\text { Tilio-Carpinetum } \\
\text { rich variant (II) }\end{array}$ & -0.7 & -68.3 & 67.6 & -23.4 \\
$\begin{array}{c}\text { Tilio-Carpinetum } \\
\text { typical variant (IV) }\end{array}$ & -10.7 & -83.5 & 72.9 & -36.2 \\
$\begin{array}{c}\text { Tilio-Carpinetum } \\
\text { poor variant (V) } \\
\text { Pino-Quercetum } \\
\text { rich variant (VI) }\end{array}$ & -15.5 & -103.8 & 88.3 & -48.4 \\
$\begin{array}{c}\text { Pino-Quercetum } \\
\text { typical variant (VII) }\end{array}$ & -52.1 & -131.0 & 78.9 & -82.9 \\
$\begin{array}{c}\text { Pino-Quercetum } \\
\text { moist variant (VIII) }\end{array}$ & -3.7 & -86.8 & 83.1 & -34.5 \\
\hline
\end{tabular}

a - average maximum annual consistency, b-average minimum annual consistency, c - average annual amplitude, d - average consistency in period of research work

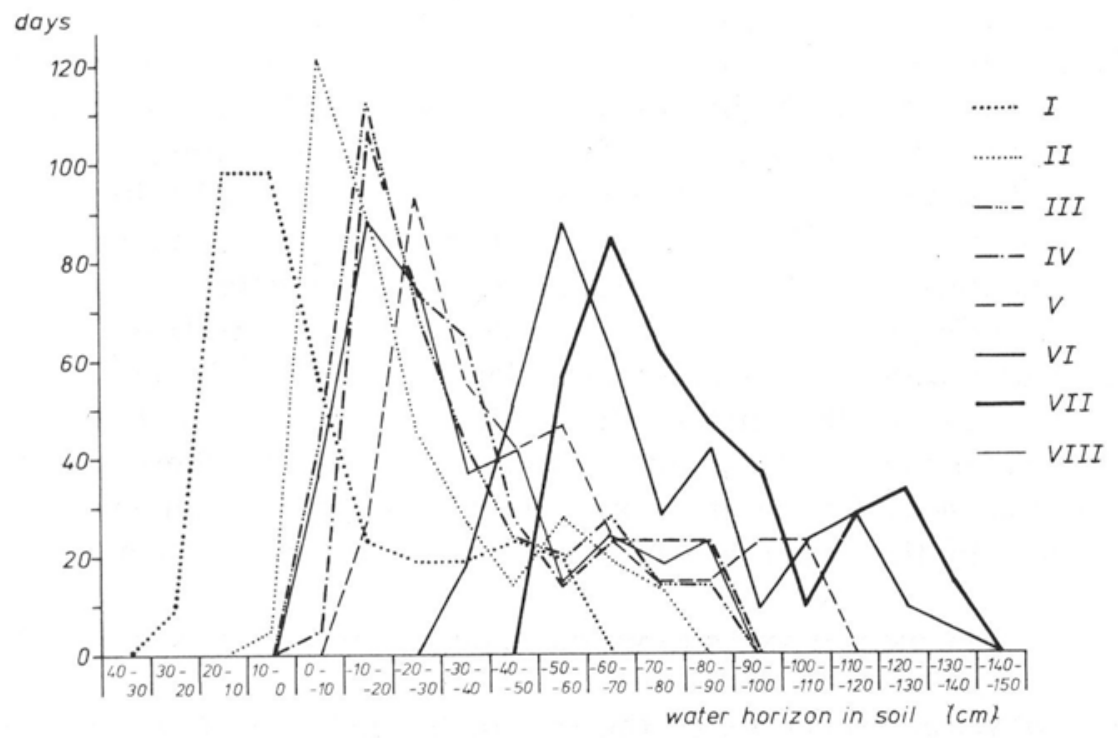

Fig. 5. Distribution of frequency of occurrence of definite water horizons in the particular plant communities

dating water is of little consequence. The Circaeo-Alnetum flood plain forests are associated, on the other hand, with habitats where the ground 
water remains for a considerable part of the year very close to the soil surface, but there is in general no flooding. These habitats are characterised by relatively small annual variation amplitudes of the water horizon. The Tilio-Carpineta occupy habitats where the ground water level remains for a great part of the year at a level of $10-40 \mathrm{~cm}$. The internal phytosociological differentiation of these communities is only partly associated with differences in the depth of the water horizon. It would seem that the differences in Tilio-Carpineta are due to other habitat factors spatially differentiated, and partly coupled with the ground water horizon. The mixed moist coniferous forest community occupies, as regards the depth of the water horizon, habitats analogous to those of the Tilio-Carpineta. The mixed moist coniferous forests, however, occur on different sites (Fig. 1), namely, on the borders of the depression with restricted run-off, whereas Tilio-Carpineta lie on the edges of the water course valley. The reason for this is probably the difference in the richness of the substrate ( $\mathrm{Cz}$ e rwiński et al. 1974 , Matuszkiewicz W. 1974) and also the differences in the horizontal mobility of the ground water. Mixed fresh coniferous forest (VI and VII) occupy habitats quite distinct from the others. The ground water horizon lies there so deep that under sandy substrate conditions it cannot influence directly the surface soil where most of the plants of the herb layer have their roots. Owing to this, fresh mixed coniferous forests show a high tolerance to the depth of the ground water horizon.

It results from the foregoing that alder forests and mixed fresh coniferous forests are highly tolerant to the ground water depth. Thus, these communities occupy larger areas than the remaining ones. From the aspect of the ground water horizon three types of habitats can be distinguished on the investigated territory: innundated habitats (alder forest), habitats not flooded but with a high ground water horizon (floodplain, Tilio-Carpinetum and mixed moist coniferous forest) and habitats with ground water at a considerable depth (mixed fresh coniferous forest). It is noteworthy that in the habitats of the first and third type the differentiation of the plant communities is slight, whereas in habitats of the second type it is important and depends on even slight differences in the water horizon and other habitat conditions.

SEASONAL CHANGES IN MOISTURE OF SURFACE SOIL LAYER

The physical properties of the soil in the habitats of the particular plant communities differ widely (Fig. 6). The solid particles level is lowest in the peat soil of alder forests, it is much higher in the neighbouring floodplain forest and markedly increases in the soil of Tilio-Carpineta and still more in fresh coniferous forests. The capillary water capacity of the soil, on the contrary, is highest in alder forests and 
lowest in mixed coniferous forests. The volume of spaces larger than capillary spaces, that is porosity to air, also shows marked differences in the plant communities. It is very low in the soils of alder and floodplain forests and increases gradually in the transition to Tilio-Carpineta and mixed coniferous forest. A distinct, unequivocal variability of physical properties is noticeable within the whole range. This variability agrees well with the phytosociological ordering of the plant communities and with their distribution in this area.
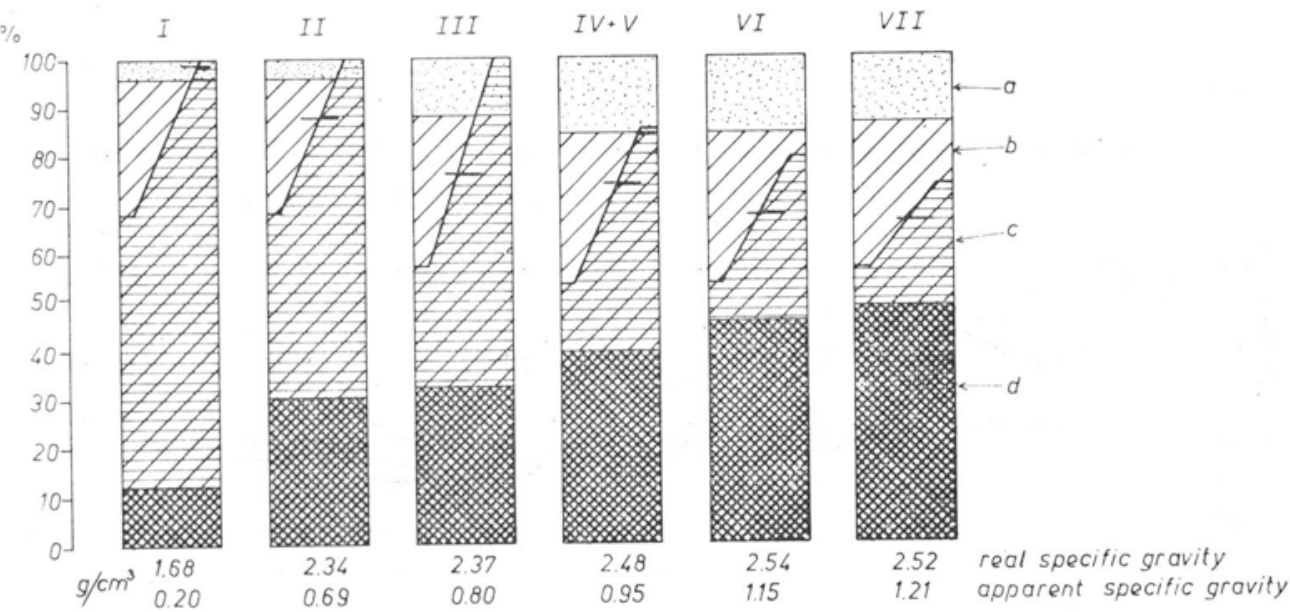

Fig. 6. Physical properties of soils in the plant communities a - volume of spaces larger than capillary ones, b - volume of capillary spaces, c - spaces filled with water (extremal and mean states), d - solid particles volume in soil

The differences in soil moisture in the "Grabowy" range (Fig. 7 and Table 2) are the result of differences in the physical properties of the soils and of the unequal depth of the ground water horizon. The differences in soil moisture in the surface layer between the plant communities are even wider than the seasonal variability. The moisture of the surface soil layer differentiates the plant communities into four types, and, what is significant, this division agrees with the main phytosociological division of the communities into plant associations. The first type consists of alder forest habitats where the soil is sodden for the greater part of the year and dries only slightly in late summer. To the second type belong Circaeo-Alnetum habitats where the surface soil layer is only innundated in winter and early spring and sporadically in other seasons. The moisture of the surface soil layer varies widely in the flood plain forest in the course of the year, but is always high (above 60\% of capillary capacity). The Tilio-Carpinetum habitats belong to the third type. The moisture of the surface soil layer is here high in general and gradually changes in the course of the seasons without drastic variations. Innundation of the surface soil layer owing to a rise of the water hori- 
zon occurs only sporadically. The fourth type of moisture conditions is represented by habitats with mixed fresh coniferous forest, They are characterised by the lowest soil moisture and relatively small changes in the course of the year. In the driest period the moisture of the surface soil layer falls below $10 \mathrm{ml} / 100 \mathrm{~cm}^{3}$, owing to which the water is but little accessible to the plants ( $\mathrm{Uggla}$ and $\mathrm{Uggla}$ 1979). This is an important difference as compared with the habitats of other plant communities in this range.
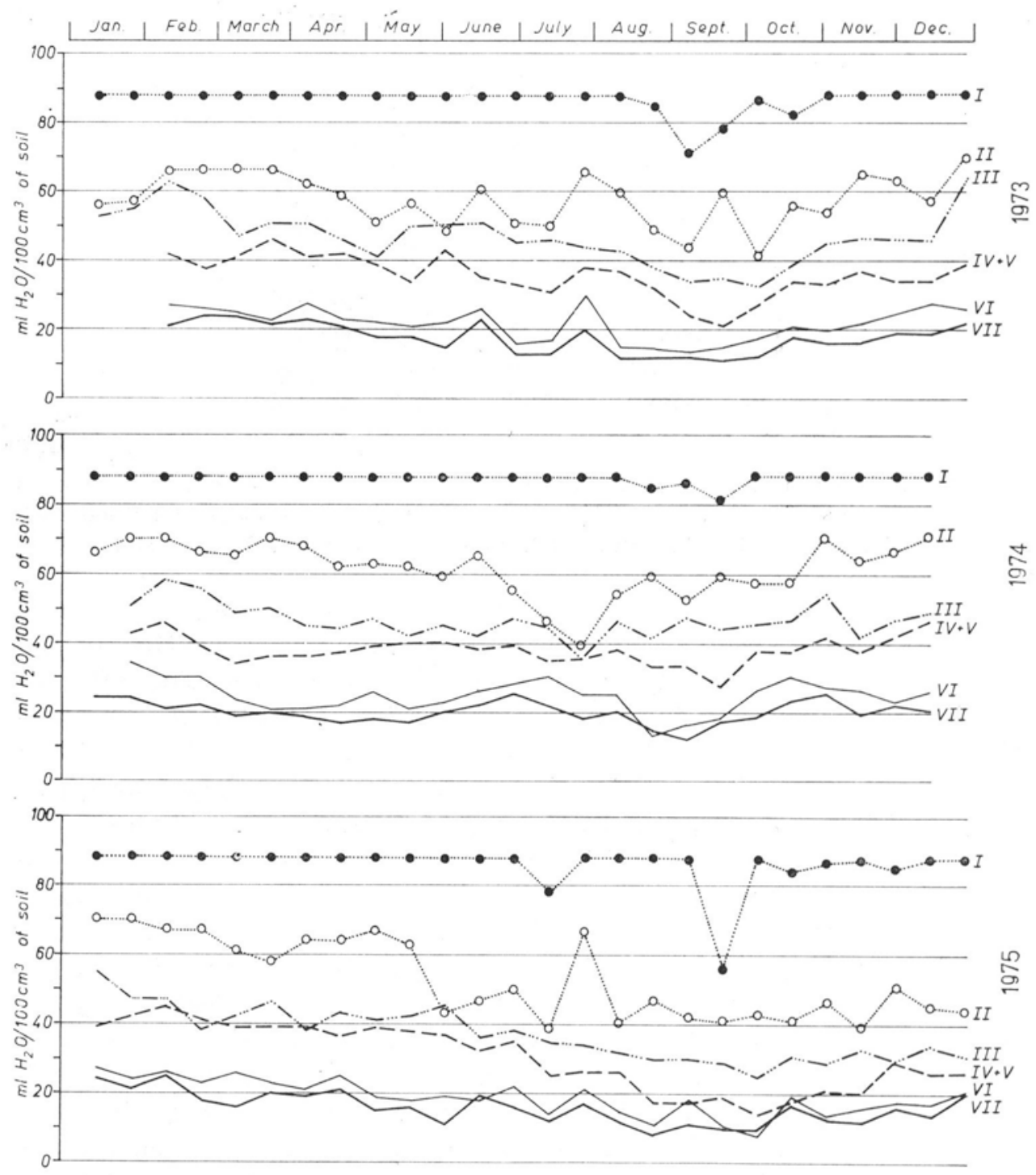

Fig. 7. Moisture variations in surface soil layer in plant communities in the studied period (millilitres of water per $100 \mathrm{~cm}^{3}$ of soil with intact structure) 
Table 2

Physical characteristics of surface soil in plant communities of "Grabowy" range

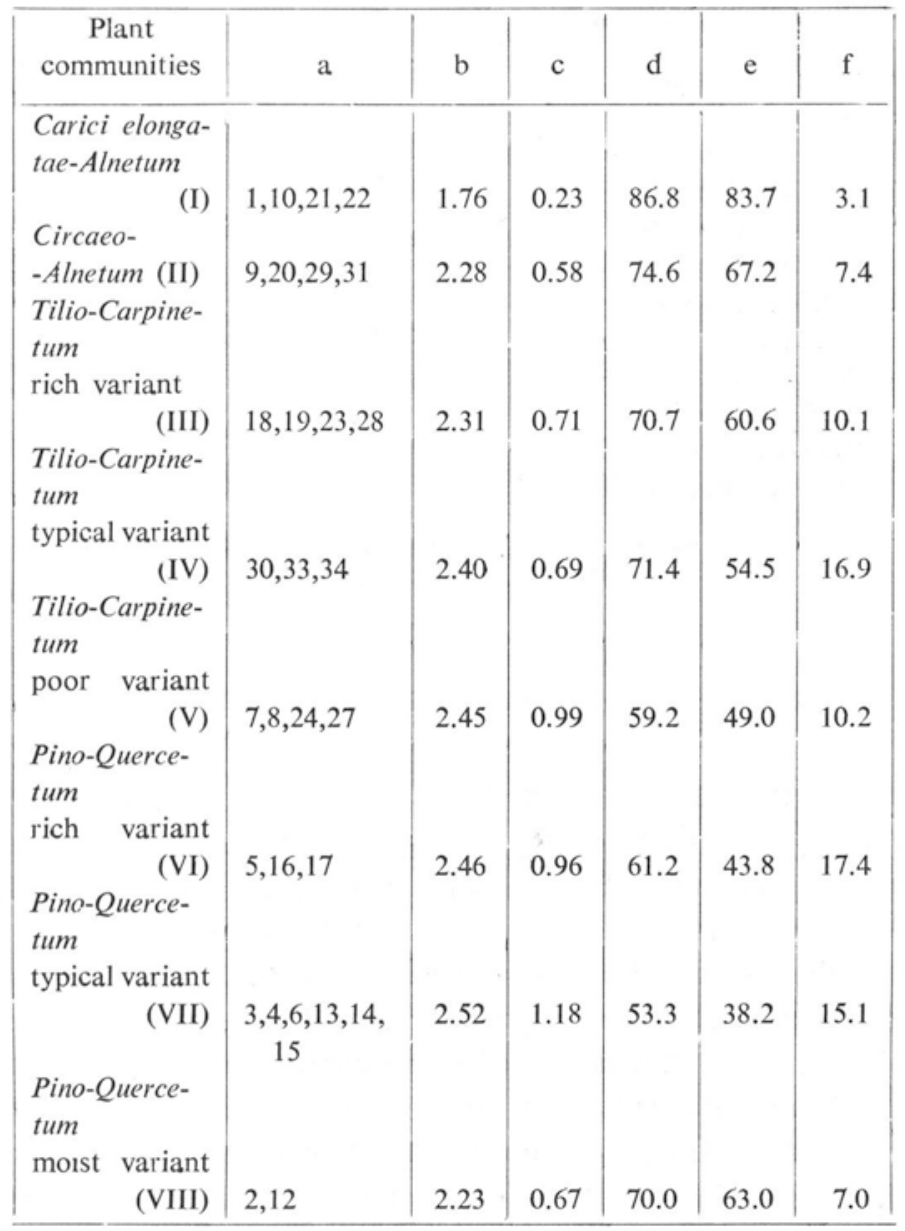

a-numbers of measuring sites (underscored sites refer to investigations of moisture dynamics), b - real specific gravity, c - apparent specific gravity, d - total porosity, e - capillary water capacity, $\mathrm{f}$ - permeability for air

The moisture and physical properties of the soil condition the air content in the surface soil layer. As seen in Table 3, the amount of air in the soil diminishes as we pass from mixed fresh coniferous forest to alder forest. This fact is of high ecological importance since most organisms decomposing dead organic matter require good aeration of the soil ( $\mathrm{Rich}$ a rds 1979). It is, therefore, obvious that the changes of breakdown of organic matter in the particular plant communities will not be the same. 
Table 3

Air content in surface soil in plant communities of "Grabowy" range

\begin{tabular}{|l|c|c|c|c|}
\hline \multirow{2}{*}{ Plant communities } & \multicolumn{4}{|c|}{ Air content in soil, \% } \\
\cline { 2 - 5 } & $\mathrm{a}$ & $\mathrm{b}$ & $\mathrm{c}$ & $\mathrm{d}$ \\
\hline $\begin{array}{c}\text { Carici elongatae- } \\
\quad \text {-Alnetum (I) }\end{array}$ & 19.0 & 0.0 & 19.0 & 1.3 \\
$\begin{array}{l}\text { Circaeo-Alnetum (II) } \\
\text { Tilio-Carpinetum } \\
\text { rich variant (III) }\end{array}$ & 30.8 & 0.0 & 30.8 & 12.8 \\
$\begin{array}{c}\text { Tilio-Carpinetum } \\
\text { typical and poor } \\
\text { variant }\end{array}$ & 37.0 & 9.1 & 27.9 & 24.2 \\
$\begin{array}{c}\text { Pino-Quercetum } \\
\text { rich variant (VI) }\end{array}$ & 42.6 & 24.7 & 17.9 & 32.5 \\
$\begin{array}{c}\text { Pino-Quercetum } \\
\text { typical variant (VII) }\end{array}$ & 41.4 & 27.4 & 14.0 & 33.9 \\
\hline
\end{tabular}

a - average maximum annual consistency, b-average minimum annual consistency, c - average annual amplitude, d - average consistency in period of research work

\section{CONCLUSIONS}

The present results allow general conclusions concerning the relations between plant differentiation and variations in the water conditions. Under conditions of a uniform geological substrate the depth of the ground water horizon is the main factor leading to the formation of a zonation series of plant communities in the landscape phytocomplex. Within the latter at least two types of zonation series can be distinguished: that is series of spatial plant community succession, namely: a series running from the ridge of the eminence to the depressions with restricted run-off. Thus, the gradient of ground water depth causes a differentiation of the vegetation in zonation series, however, the particular positions in the series may be sometimes occupied by various plant communities in dependence on other factors. This means that the differences in the water conditions produce a regular differentiation of the plant communities in space, however, under the same water conditions the plant communities occurring here may vary within a certain range.

As it results from the foregoing, the correctness of the method adopted by the author (M t tuszkiewicz J. M. 1978, 1979b, 1981) of a standardized description of the differentiation of the plant communities in the landscape phytocomplex is confirmed. In this method the principle was adopted that the main factor ordering the distribution of plant communities in the zonation series are the water conditions in the substrate, dependent on the terrain relief. The correctness of distinguis- 
hing two zonation series in landscape phytocomplexes of lowland areas is also confirmed.

\title{
REFERENCES
}

Czerwiński Z., Roo-Zielińs k a E. M., C z erwińs k a K., 1974. Gleby rezerwatu „Grabowy” w Puszczy Kampinoskiej. Phytocoenosis 3: 17-42.

Fabijanowski J., Zarzycki K., 1967. Wody gruntowe w zbiorowiskach leśnych nadleśnictwa Bliżyn (Góry Świętokrzyskie). Acta Agrar. Silv. Ser. Silv. 7: 3-41.

K w olczak J., 1974. Zbiorowiska roślinne rezerwatu „Grabowy” w Puszczy Kampinoskiej. Phytocoenosis 3: 3-16.

Matuszkiewicz J. M., 1978. Fitokompleks krajobrazowy - specyficzny poziom organizacji roślinności. Wiad. Ekol. 24: 3-13.

M a tuszkiewicz J. M., 1979a. Landscape photocomplexes and vegetation landscapes, real and typological landscape units of vegetation. Docum. Phytosociol. N. S. 4: 663-672.

Matuszkiewicz J. M., 1979b. Potential landscape photocomplexes of Sudety Mountains. Acta Soc. Bot. Pol. 48: 3-25.

M a tuszkie wi c z J. M., 1981. Auswertung mittelmasstäblicher Karten der potentiell natürlichen Vegetation zur Abgrenzung ökologisch-landschaftlicher Raumeinheiten. Arch. Naturschutz Landschaftsforsch. 21: 21-33.

M a tuszkiewicz W., 1974. Próba systematyzacji warunków środowiska glebowego w zbiorowiskach leśnych. Phytocoenosis 3: 113-170.

R i chards B. N., 1979. Wstęp do ekologii gleby. PWN, Warszawa.

Ug g l a H., Ug gla Z., 1979. Gleboznawstwo leśne. PWRiL, Warszawa.

\section{Wody gruntowe jako czynnik przewodni zróżnicowania roślinności naturalnej $w$ fitokompleksie krajobrazowym (Uroczysko "Grabowy" w Puszczy Kampinoskiej)}

\author{
Streszczenie
}

Badania prowadzone były w uroczysku „Grabowy” w Puszczy Kampinoskiej w latach 1973-75. Na obszarze uroczyska wyznaczono 34 punkty, reprezentujące następujące typy zbiorowisk: I - ols (Carici elongatae-Alnetum), II - łęg jesionowo-olszowy (Circaeo-Alnetum), III — grąd (Tilio-Carpinetum) wariant żyzny, IV grąd wariant typowy, V - grąd wariant ubogi, VI - bór mieszany (Pino-Quercetum) wariant żyzny, VII — bór mieszany wariant typowy, VIII — bór mieszany wariant wilgotny. Co dwa tygodnie mierzono głębokość zalegania wód gruntowych oraz wilgotność gleby w warstwie powierzchniowej. Uzyskane wyniki wskazują, że równolegle ze zmiennością w przestrzeni poziomu wód gruntowych realizuje się fitosocjologiczne zróżnicowanie zbiorowisk roślinnych. Także równolegle ma miejsce zmienność fizycznych właściwości gleby oraz jej wilgotności i zasobu powietrza w wierzchniej warstwie. Wyniki wykazują ścisły, ale w określonym stopniu nie jednoznaczny, związek między zmiennością przestrzenną stosunków wodnych a zróżnicowaniem zbiorowisk roślinnych w fitokompleksie krajobrazowym i potwierdzają słuszność przyjętego wcześniej przez autora schematu przedstawiania struktury potencjalnych fitokompleksów krajobrazowych. 